\title{
Gambaran Sarana dan Prasarana Bimbingan dan Konseling pada Sekolah Menengah Negeri di Indonesia
}

\author{
Marimbun Marimbun ${ }^{* 1}$, Rizky Andana Pohan² \\ 1,2 Program Studi Bimbingan dan Konseling Islam, Institut Agama Islam Negeri (IAIN) \\ Langsa, Aceh, Indonesia. \\ *)Corresponding author, $\equiv$ e-mail: marimbun@iainlangsa.ac.id
}

\begin{tabular}{ccc} 
Received: & Accepted: & Published: \\
11 October 2021 & 28 November 2021 & 31 December 2021 \\
\hline
\end{tabular}

\begin{abstract}
The implementation of effective guidance and counselling services requires adequate facilities and infrastructure in accordance with national standards in Permendikbud No 111 of 2014 regarding guidance and counselling in secondary education in Indonesia. This study aims to describe the condition of the facilities and infrastructure for guidance and counselling in state secondary school; junior and senior state high school in Indonesia. The method used is the survey model. The research data were collected from 65 State Senior High Schools, 25 State Vocational High Schools and 58 State Junior High Schools spread over 71 districts/cities in 18 provinces in Indonesia. The instrument used a semi-open questionnaire adopted from Permendikbud No. 111 of 2014 regarding guidance and counselling in primary and secondary education. The results of the study showed as many as $4.68 \%$ of state senior high schools and $8.77 \%$ of state junior high schools did not have a counselling room. A total of $20.31 \%$ of state senior high schools, $58.82 \%$ of state vocational high schools, and $52.63 \%$ of state junior high schools did not have special room for individual counselling. A total of $10.93 \%$ of state high schools, $52.94 \%$ of state vocational high schools and $21.05 \%$ of state junior high schools did not have living room. A total of $39.06 \%$ of state senior high schools, $64.70 \%$ of state vocational high schools, and $64.91 \%$ of state junior high schools did not have group guidance and counselling rooms. A total of $31.25 \%$ of state senior high schools, $35.29 \%$ of state vocational high schools, and $59.64 \%$ of state junior high schools did not have data room. As many as $31.25 \%$ of state senior high schools, $82.35 \%$ of state vocational high schools, and $73.68 \%$ did not have library display room (bibliocounseling). This study revealed that the facilities and infrastructure for guidance and counseling in state secondary schools in Indonesia do not in accordance with the minimum standards issued in Permendikbud No. 111 of 2014. The implementation of effective and efficient guidance and counselling services requires facilities and infrastructure that corresponds with the minimum standards. Based on this study results, it is anticipated the stakeholders of guidance and counselling services, especially in education sections in Indonesia, would pay attention and provide the minimum standard of guidance and counselling facilities and infrastructure.
\end{abstract}

Keywords: Facilities and Infrastructure, Guidance and Counselling, Permendikbud No 111 of 2014

\begin{abstract}
Abstrak
Pelaksanaan layanan bimbingan dan konseling yang efektif membutuhkan sarana dan prasarana yang memadai sesuai dengan standar nasional dalam Permendikbud No 111 Tahun 2014 tentang bimbingan dan konseling pada pendidikan menangah di Indonesia. Kajian ini bertujuan untuk mendeskripsikan keadaan sarana dan prasarana bimbingan dan konseling pada SMP dan SMA Negeri di Indonesia. Metode yang digunakan model survey. Subjek penelitian sebanyak 65 SMA Negeri, 25 SMK Negeri dan 58 SMP Negeri yang tersebar dalam 71 kabupaten/ kota pada 18 Provinsi yang ada di Indonesia. Instrumen menggunakan angket semi terbuka yang diadopsi dari Permendikbud No 111 Tahun 2014 tentang BK pada pendidikan dasar dan menengah. Hasil kajian menunjukkan bahwa sebanyak 4,68\% SMA Negeri dan 8,77\% SMP Negeri belum memiliki ruang BK. Sebanyak 20,31\% SMA Negeri, 58,82\% SMK Negeri, dan 52,63\% SMP Negeri belum memiliki ruang khusus konseling individu. Sebanyak 10,93\% SMA Negeri, 52,94\% SMK Negeri dan 21,05\% SMP Negeri belum memiliki ruang tamu. Sebanyak $39,06 \%$ SMA Negeri, 64,70\% SMK Negeri, dan 64,91\% SMP Negeri belum memiliki ruang bimbingan dan
\end{abstract}


konseling kelompok. Sebanyak 31,25\% SMA Negeri, 35,29\% SMK Negeri, dan 59,64\% SMP Negeri belum memiliki ruang data. Sebanyak 31,25\% SMA Negeri, 82,35\% SMK Negeri, dan 73,68\% yang belum memiliki ruang tamipan kepustakaan (bibliocounseling). Kajian ini mengungkapkan bahwa sarana dan prasarana bimbingan dan konseling di SMA Negeri, SMK Negeri dan SMP Negeri di Indonesia belum memenuhi standar minimal sesuai dengan Permendikbud No 111 Tahun 2014. Penyelenggaraan layanan bimbingan dan konseling yang efektif dan efisien memerlukan sarana dan prasarana yang memenuhi standar minimal. Berdasarkan kajian ini diharapkan para pemangku kepentingan pelayanan BK terkhusus di satuan pendidikan di Indonesia dapat memperhatikan dan memenuhi standar sarana dan prasarana minimal BK.

Kata Kunci: Sarana dan Prasarana, Bimbingan dan Konseling, Permendikbud No 111 Tahun 2014

This is an open access article distributed under the Creative Commons Attribution License, which permits unrestricted use, distribution, and reproduction in any medium, provided the original work is properly cited. (C2021 by author.

\section{PENDAHULUAN}

Bimbingan dan konseling menjadi bagian integral sistem pendidikan di setiap satuan pendidikan yang berupaya memfasilitasi dan memandirikan peserta didik agar mencapai perkembangan yang utuh dan optimal (Tim Penyusun Panduan Bimbingan Dan Konseling Sekolah Dasar, Sekolah Menengah Pertama, Sekolah Menengah Atas, 2016). Keberadaan layanan bimbingan dan konseling membantu untuk mewujudkan tujuan pendidikan nasional. Oleh karena itu, perlu adanya sarana dan prasarana yang memadai (Kemendikbud, 2014).

Pelaksanaan layanan bimbingan dan konseling di satuan pendidikan dapat berjalan dengan efektif membutuhkan sarana dan prasarana yang memadai.

Peraturan Menteri Pendidikan Nasional Republik Indonesia No 24 Tahun 2007 tentang Standar Sarana dan Prasarana untuk Sekolah dengan tegas menyatakan bahwa di satuan pendidikan wajib mempunyai sarana yang dibutuhkan untuk mempermudah proses pembelajaran. Oleh karena itu, sekolah berupaya menpersiapkan sarana dan prasarana yang sesuai dengan standar, sehingga memudahkan terwujudnya tujuan pendidikan yang optimal (Kemendiknas, 2007).

Menurut Indrawati (Indrawan, 2015), sarana dan prasarana dimanfaatkan untuk keperluan proses pendidikan di sekolah. pendayagunaan sarana dan prasarana pendidikan diperlukan untuk mendukung proses pendidikan untuk mewujudkan tujuan pendidikan. Sarana dan prasarana menjadi motor penggerak yang dapat digunakan untuk percepatan dalam mewujudkan capaian pendidikan. Begitu pula dengan sarana dan prasarana bimbingan konseling (Sugiarto, S., Neviyarni, S., \& Firman, 2021), Sarana dan prasarana bimbingan dan konseling mempermudah pelaksanaan pelayanan bimbingan dan konseling sehingga dapat menunjang tercapainya tujuan pelaksanaan layanan bimbingan dan konseling (Kemendikbud, 2014). Kelengkapan sarana dan prasarana mampu memberikan andil yang cukup besar terhadap keefektifan pelaksanaan layanan bimbingan dan konseling di seluruh elemen. Hal ini pula yang mendorong pemerintah mengeluarkan standar pelayanan minimal 
BK di satuan pendidikan dalam Permendikbud No 111 Tahun 2014.

Hasil penelitian Bhakti (Bhakti, 2018), menunjukkan bahwa kebanyakan sekolah belum memiliki sarana dan prasarana bimbingan dan konseling seperti ruang administrasi, ruang konseling individu, dan ruang bimbingan dan konseling kelompok. Berdasarkan penelitian Intishar, dkk (Intishar, F., Chanum, I., \& Badrujaman, 2015) tentang pemenuhan standar fasilitas bimbingan dan konseling di sekolah menengah atas bahwa dari 14 sekolah yang di survey hanya 1 sekolah memenuhi standar dan 13 sekolah tidak memenuhi standar. Sejalan dengan itu, hasil penelitian Putranti (Putranti, 2015) bahwa ruang bimbingan dan konseling di sekolah belum memadai. Salah satu hambatan terbatasnya ruang bimbingan dan konseling di sekolah adalah faktor biaya. Sementara penelitian Novita (Novita, 2017), mengungkapkan bahwa sarana dan prasarana merupakan ujung tombak terhadap kemajuan lembaga pendidikan. Selain itu, sarana dan prasarana dapat mendorong minat peserta didik dalam pemanfaatan layanan bimbingan dan konseling. Artinya, semakin terpenuhi standar sarana dan prasarana bimbingan dan konseling maka semakin kuat minat peserta didik dalam memanfaatkan layanan bimbingan dan konseling, dan sebaliknya semakin kurang sarana dan prasarana bimbingan dan konseling maka semakin rendah minat peserta didik dalam memanfaatkan layanan bimbingan dan konseling di sekolah (Zahara, 2017).

Beberapa hasil penelitian terdahulu menunjukkan tentang pentingnya sarana dan prasarana dalam pelayanan bimbingan dan konseling di Sekolah (Sugiarto, S., Neviyarni, S., \& Firman, 2021). Selanjutnya untuk mencapai tujuan pelaksanaan layanan bimbingan dan konseling di sekolah yang optimal dibutuhkan sarana dan prasarana yang memadai (Fitria, L., Neviyarni, S., Syukur, Y., \& Ahmad, 2021). Oleh karena itu, menurut Farozin, dkk (Farozin, M., Suwarjo, S., \& Astuti, 2017), guru bimbingan dan konseling perlu membuat anggaran biaya dan pengadaan sarana dan prasarana berdasarkan Peraturan Pemerintah No. 27 tahun 2008 terkait Standar Kualifikasi Akademik dan Kompetensi Konselor bahwa guru bimbingan dan konseling harus memiliki kompetensi merencanakan sarana dan biaya penyelenggaraan program bimbingan dan konseling.

Beberapa hasil penelitian lainnya juga menunjukkan pentingnya sarana dan prasarana sebagai penunjang kegiatan bimbingan konseling di sekolah. Berdasarkan beberapa kajian terdahulu tersebut perlu adanya survey yang lebih luas di Indonesia untuk melihat bagaimana kesediaan sarana dan prasarana di sekolah seperti di SMA Negeri, SMK Negeri dan SMP Negeri yang seharusnya memenuhi standar sarana dan prasarana minimum agar penyelenggaraan pelayanan konseling di sekolah dapat berjalan dengan efektif. Tujuh tahun berjalan sejak dikeluarkannya Permendikbud No 111 Tahun 2014 perlu adanya kajian sudah sejauh mana 
penerapannya dilaksanakan oleh satuan pendidikan.

Kajian ini akan menggambarkan keadaan sarana dan prasarana bimbingan dan konseling di SMA Negeri, SMK Negeri dan SMP Negeri yang lebih luas yang berada di Indonesia berdasarkan permendikbud No 111 Tahun 2014. Melalui kajian ini diharapkan dapat menggambarkan bagaimana sarana dan prasarana di sekolah negeri sehingga dapat menjadi pertimbangan untuk para pengambil kebijakan, karena pelaksanaan layanan bimbingan dan konseling yang efektif membutuhkan sarana dan prasarana minimal sesuai dengan yang telah ditetapkan oleh pemerintah.

\section{METODE}

Kajian ini menggunakan penelitian model survei. Subjek penelitian sebanyak 65 SMA Negeri, 25 SMK Negeri dan 58 SMP Negeri yang berada di 71 Kabupaten/ Kota, pada 18 Provinsi seperti Pulau Sumatera (Aceh, Sumatera Utara, Sumatera Barat, Bengkulu, Riau, Kepulauan Riau, Lampung). Pulau Kalimantan (Kalimantan Barat, Kalimantan Timur, Kalimantan Selatan, Kalimantan Tengah). Pulau Jawa (Banten, DKI Jakarta, Jawa Barat, Jawa Tengah, DI Yogyakarta, Jawa Timur) dan Pulau Nusa Tenggara \& Bali (Bali). Instrumen yang digunakan adalah angket semi terbuka dengan metode checklist mengacu kepada standar sarana dan prasarana Permendikbud No 111 Tahun 2014. Pelaksanaan survey dilakukan melalui google formulir yang dibagikan kepada konselor/ guru-guru BK di bulan

April 2021 ketika pelaksanaan Seminar Nasional Manajemen BK di Satuan Pendidikan dan Perguruan Tinggi yang dilaksanakan oleh Abkin Kota Langsa. Analisis data yang digunakan adalah deskriptif dengan teknik persentase.

\section{HASIL TEMUAN}

Hasil penelitian menguraikan sarana dan prasarana bimbingan dan konseling di sekolah negeri berdasarkan hasil survey di 65 Sekolah Menengah Atas (SMA) Negeri, 25 Sekolah Menengah Kejuruan (SMK) Negeri, dan 58 Sekolah Menengah Pertama (SMP) Negeri pada 71 kabupaten/ kota yang ada di Indonesia. Standar sarana dan prasarana BK yang digunakan mengacu kepada Peraturan Menteri Pendidikan dan Kebudayaan No 111 Tahun 2014 tentang Bimbingan dan Konseling pada Pendidikan Dasar dan Pendidikan Menengah. Pelaksanaan layanan bimbingan dan konseling membantu mewujudkan tujuan pendidikan nasional. Penyelenggaraan layanan bimbingan dan konseling yang efektif dan efisien memerlukan sarana dan prasarana. Adapun kebutuhan ruang bimbingan dan konseling: ruang kerja BK, ruang konseling individual, ruang tamu, ruang bimbingan dan konseling kelompok, ruang data, ruang konseling pustaka (bibliocounseling) dan fasilitas penunjang seperti alat pengumpul data serta penyimpan data. Hasil survey ini juga membahas kenyamanan ruangan, keterjaminan privasi peserta didik, apa saja hambatan dalam menyediakan sarana dan 
prasarana BK, harapan guru-guru BK terkait sarana dan prasarana.

Hasil survey sarana dan prasarana bimbingan dan konseling dengan standar ruang BK dapat dilihat pada gambar 1 tentang sarana dan prasarana BK di SMA Negeri.

Gambar 1. Sarana dan Prasarana BK di SMA Negeri

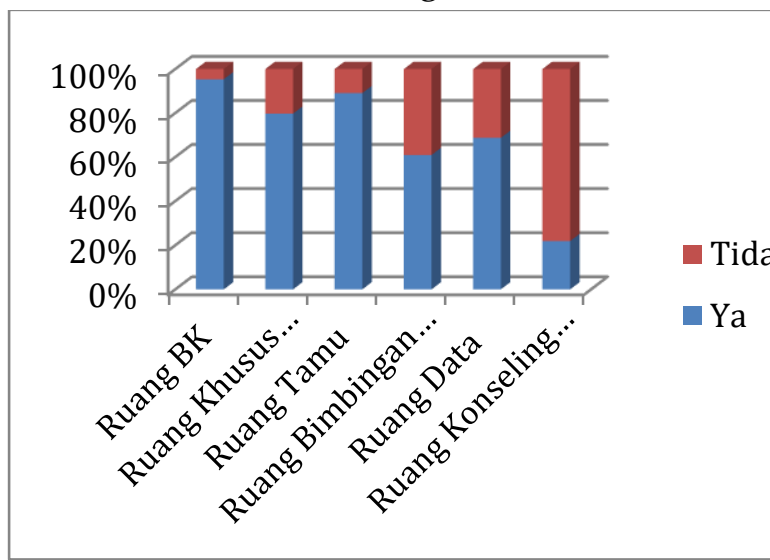

Berdasarkan gambar 1 menunjukkan bahwa sarana dan prasarana bimbingan dan konseling di SMA Negeri bahwa masih ada 4,68\% yang belum memiliki ruang BK, 20,31\% yang belum memiliki ruang khusus konseling individu, $10,93 \%$ yang belum memiliki ruang tamu, $39,06 \%$ yang belum memiliki ruang bimbingan dan konseling kelompok, $31,25 \%$ yang belum memiliki ruang data, $31,25 \%$ yang belum memiliki ruang tampilan kepustakaan (bibliocounseling).

Gambar 2. Sarana dan Prasarana BK di SMK Negeri

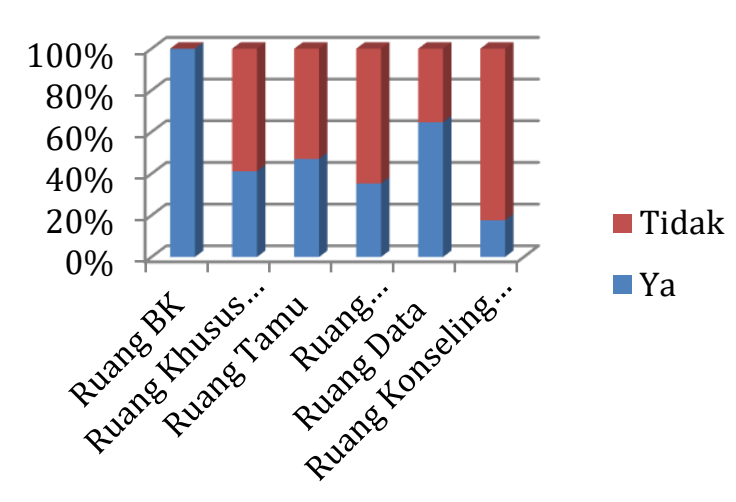

Berdasarkan gambar

menunjukkan bahwa sarana dan prasarana bimbingan dan konseling di SMK Negeri bahwa semua yang di survey sudah memiliki ruang BK, 58,82\% yang belum memiliki ruang khusus konseling individu, $52,94 \%$ yang belum memiliki ruang tamu, $64,70 \%$ yang belum memiliki ruang bimbingan dan konseling kelompok, $35,29 \%$ yang belum memiliki ruang data, $82,35 \%$ yang belum memiliki ruang tampilan kepustakaan (bibliocounseling).

Gambar 3. Sarana dan Prasarana BK di SMP Negeri

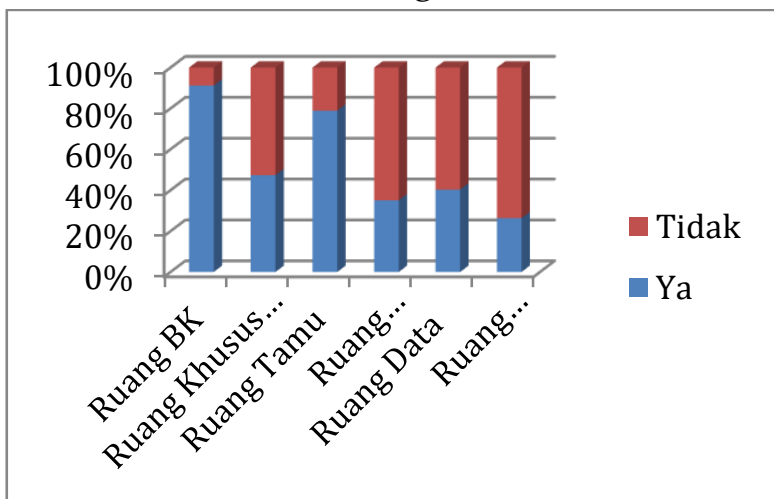

Berdasarkan Gambar 3 bahwa sarana dan prasarana bimbingan dan konseling di SMP Negeri bahwa masih ada 8,77\% yang belum memiliki ruang $\mathrm{BK}$, $52,63 \%$ yang belum memiliki ruang khusus 
konseling individu, 21,05\% yang belum memiliki ruang tamu, 64,91\% yang belum memiliki ruang bimbingan dan konseling kelompok, 59,64\% yang belum memiliki ruang data, $73,68 \%$ yang belum memiliki ruang tampilan kepusatakaan (bibliocounseling).

\section{PEMBAHASAN}

Ruang kerja bimbingan dan konseling sangat berkontribusi untuk keberhasilan pelaksanaan layanan bimbingan dan konseling pada satuan pendidikan. Ruang kerja bimbingan dan konseling disiapkan dengan ukuran yang memadai, dilengkapi dengan perlatan yang dibutuhkan, ruang bimbingan dan konseling bertempat di lokasi yang mudah untuk akses layanan dan berada pada lingkungan yang sehat. Di samping ruangan bimbingan dan konseling, dapat dibangun taman sekolah yang berfungsi ganda yaitu untuk kepentingan taman satuan pendidikan, dapat juga ada disain untuk layanan bimbingan dan konseling di taman (Kemendikbud, 2014).

Fasilitas BK harus menjadi hal yang eksklusif terutama di satuan pendidikan (Hikmawati, 2016). Sementara itu, BSNP (BSNP, 2006), memberikan gambaran yang terkait standar sarana Bimbingan dan Konseling di sekolah, seperti ruang konseling yang berfungsi menjadi tempat peserta didik untuk memperoleh layanan konseling dari konselor/ guru BK yang berkaitan dengan pengembangan kehidupan pribadi, sosial, belajar, dan karier. Luas minimum ruang konseling 9 $\mathrm{m}^{2}$, sehingga ruang konseling dapat memberikan kenyamanan suasana dan menjamin privasi peserta didik, Ruang konseling dilengkapi berbagai sarana penunjang lainnya.

Hasil kajian di Indonesia menunjukan bahwa di SMA Negeri terdapat $4,68 \%$ yang belum memiliki ruang kerja. Di SMP Negeri terdapat 8,77\% yang belum memiliki ruang BK. Hasil survey juga menunjukkan bahwa ruangan $\mathrm{BK}$ belum memberikan kenyamanan kepada Guru BK dikarenakan berbagai hal seperti ruangan tidak mempunyai ventilasi, jendela, panas, dan tempat tidak nyaman. Kenyamanan seharusnya menjadi acuan utama dalam ruangan, begitu juga dalam ruang pelayanan bimbingan dan konseling.

Kajian berikutnya menunjukkan tentang kanyamanan dalam memberikan pelayanan, hasilnya sebanyak $18,75 \%$ Guru BK SMA Negeri tidak merasa nyaman. Di SMK Negeri sebanyak 35,29\% Guru BK tidak merasa nyaman. Di SMP Negeri sebanyak 22,80\% Guru BK merasa tidak nyaman. Beberapa alasan yang membuat Guru BK tidak merasa nyaman di ruangan BK antara lain: 1) Belum adanya ruangan khusus konseling individual sehingga belum mampu menjamin privasi sehingga peserta didik merasa terganggu ketika mendapatkan pelayanan konseling. Hal ini terdindikasi dari adanya beberapa siswa yang ingin melaksanakan konseling terpaksa menunda niatnya karena khawatir/ tidak merasa nyaman melaksanakan konseling di tempat terbuka yang tidak menjamin privasi. 2) Masih ada ruangan BK yang menyatu dengan ruangan UKS. 3) Ruangan konseling belum memadai (sempit), kurang luas, tidak sesuai jumlah guru dengan jumlah peserta didik, masih banyak ditemukan ruang bimbingan dan konseling yang tidak memenuhi standar akreditasi yaitu minimal $9 \mathrm{~m}^{2}$. 4) Fasilitas yang kurang memadai mengakibatkan pelayanan 
konseling kurang efektif. Oleh karena itu, dibutuhkan berbagai fasilitas ruang BK, sehingga diri peserta didik akan merasa nyaman (Fatchurahman, 2018).

Ruang Khusus bimbingan dan konseling berkontribusi dalam keberhasilan layanan bimbingan dan konseling. Namun masih ditemukan di SMA Negeri, SMK Negeri dan SMP Negeri yang belum memiliki ruang khusus BK. Hasil kajian menunjukkan bahwa 20,31\% SMA Negeri belum memiliki ruang khusus konseling individual. 58,82\% SMK Negeri belum memiliki ruang khusus konseling individual, 52,63\% SMP Negeri belum memiliki ruang khusus konseling individual.

Layanan konseling individual merupakan salah satu layanan dalam bimbingan dan konseling yang bersifat responsif, bertujuan pemberian bantuan mengatasi masalah konseli (Widodo, 2019). Konseling individual merupakan "jantung hatinya" pelayanan bimbingan dan konseling (Haolah et al., 2018; Prayitno, 2012; Setyaningrum, 2013). Asas yang utama dalam konseling individual adalah kerahasiaan sehingga apapun yang dibicarakan dalam proses konseling terjamin kerahasiaannya. Oleh karena itu, pentingnya ruang khusus konseling individual untuk menjaga privasi sehingga peserta didik dengan sukarela datang memanfaatkan layanan konseling individual.

Ruang bimbingan dan konseling diharapkan memiliki ruang khusus untuk tercapainya proses pelayanan bimbingan dan konseling yang bermutu. Ketersediaan ruangan khusus menjadikan peserta didik/konseli yang berkunjung merasa nyaman serta dapat menjaga asas-asas dan kode etik bimbingan dan konseling. Khusus ruangan konseling individual harus merupakan ruangan yang memberi rasa aman, nyaman dan menjamin kerahasiaan konseli (Kemendikbud, 2014).

Ruang bimbingan dan konseling merupakan tempat pelayanan konseling, terutama pelayanan konseling individual. Sehingga diperlukan ruangan yang aman dari keramaian, keriuhan dan terjaga kerahasiaan dalam proses konseling (Sugiarto, S., Neviyarni, S., \& Firman, 2021). Konseling individual merupakan hubungan interaktif antara Guru BK dengan peserta didik yang bertujuan pada perubahan perilaku, membangun kepribadian, kemampuan untuk mengatasi masalah dan kemampuan membuat keputusan. Layanan konseling individual dapat diberikan kepada peserta didik yang datang sendiri, panggilan, dan rekomendasi dari pihak lain. (Kemendikbud, 2014).

Ruang tamu merupakan salah satu ruangan yang sangat dibutuhkan di dalam ruang kerja bimbingan dan konseling yang berguna untuk menyambut siswa maupun klien yang datang. Oleh karena itu, ruang tamu sangatlah penting keberadaannya dalam ruang bimbingan dan konseling untuk memberikan kenyamanan kepada peserta didik untuk memanfaatkan pelayanan konseling. Hasil penelitian menunjukkan bahwa sebanyak 10,93\% SMA Negeri belum memilki ruang tamu. Sebanyak 52,94\% SMK Negeri belum memilki ruang tamu dan 21,05\% SMP Negeri belum memiliki ruang tamu.

Ruang tamu akan memberikan citra dari pelayan BK terbuka bagi seluruh siswa yang berkunjung. Ruang tamu memberikan kehangatan dan kenyamanan kepada pengunjung. Ruang tamu tidak perlu mewah, kesederhanaan bisa menjadi kunci. Ruang tamu menjadi salah satu ruangan yang harus ada dalam ruangan 
bimbingan dan konseling untuk menjamu para tamu yang datang seperti peserta didik, orang tua, guru, dan siapa pun yang membutuhkan pelayanan konseling. Oleh karena itu ruang tamu dapat dilengkapi dengan kursi, meja tamu, dan beberapa peralatan lain yang dapat membuat peserta didik merasa nyaman sebelum mendapatkan layanan bimbingan dan konseling.

Selanjutnya, ruang bimbingan dan konseling kelompok berguna untuk pelaksanaan bimbingan kelompok atau konseling kelompok yang diberikan kepada peserta didik dalam format kelompok. Bimbingan kelompok berupaya membantu seseorang mencapai perkembangan yang optimal yang sesuai bakat, minat, kemampuan serta nilai yang dianutnya dan dilakukan dalam kelompok (Pohan \& Indra, 2020) (Marimbun, 2021, 2019; Romlah, 2001). bimbingan kelompok merupakan proses pemberian informasi dan bantuan pada sekelompok orang dengan memanfaatkan dinamika kelompok guna mencapai suatu tujuan tertentu (Prayitno, 2004). Oleh karena itu, perlunya ruangan yang dapat digunakan untuk pelayanan konseling dalam format kelompok. Hasil kajian menunjukkan 39,06\% SMA Negeri belum memiliki ruang bimbingan kelompok. 64,70\% SMK Negeri belum memiliki ruang bimbingan dan konseling kelompok. 64,91\% SMP Negeri belum memiliki ruang bimbingan dan konseling kelompok.

Pelayanan konseling bukan hanya diberikan dalam format individual dan klasikal, namun juga diberikan dalam format kelompok seperti layanan bimbingan kelompok dan konseling kelompok. Ruangan bimbingan dan konseling kelompok diharapkan menjadi tempat nyaman untuk mewujudkan dinamika kelompok dalam interaksi antara guru bimbingan dan konseling dengan peserta didik dan peserta didik dengan peserta didik. Ruangan bimbingan kelompok perlu dilengkapi dengan kursi untuk peserta bimbingan kelompok.

Ruang tempat menyimpan data yang dibutuhkan dalam pemberian layanan konseling. Ruangan ini dapat juga berfungsi sebagai tempat menyimpan alatalat atau instrumen konseling, yang setiap saat mudah dijangkau oleh guru pembimbing untuk keperluan layanan konseling (Sugiarto, dkk, 2021). Hasil kajian ini menunjukkan bahwa 31,25\% SMA Negeri belum memiliki ruang data. 35,29\% SMK Negeri belum memiliki ruang data. 59,64\% SMP Negeri belum memiliki ruang data.

Ruang data hendaknya dapat menyimpan instrumen-instrumen bimbingan dan konseling, himpunan data peserta didik, dan berbagai data lainnya. Ruangan tersebut seharusnya mampu memuat berbagai informasi terkait dengan peserta didik. Oleh karena itu, ruangan data perlu dilengkapi dengan lemari atau sejenis yang dapat digunakan untuk menyimpan data-data terkait dengan pelayanan konseling sehingga para guru bimbingan dan konseling merasa nyaman bekerja. Kenyamanan merupakan modal utama bagi kesuksesan program layanan bimbingan dan konseling yang disediakan. (Kemendikbud, 2014). 
Ruangan Biblioterapi pada prinsipnya mampu menjadi tempat bagi para siswa dalam menerima berbagai informasi, baik informasi yang berkenaan dengan pribadi, sosial, akademik maupun karier di masa mendatang. Ruangan ini dilengkapi dengan perlengkapan daftar buku (katalog), rak buku, ruang baca, buku daftar pengunjung, dan jika memungkinkan disediakan internet. Hasil kajian menunjukkan bahwa 31,25\% SMA, 82,35\% SMK Negeri dan 73,68\% SMP Negeri belum memiliki ruang tampilan kepustakaan (bibliocounseling).

Fasilitas penunjang yang diperlukan dalam bimbingan dan konseling seperti alat pengumpul data berupa tes dan non-tes. Hasil kajian menunjukkan seluruh sekolah telah memiliki alat instrumentasi BK. Instrumen pengumpulan data yang paling banyak digunakan di SMA Negeri adalah AUM, ITP, IKMS, DCM, AKPD, Sosiometri Dsb. Di SMK Negeri DCM. AUM, AKPD, IKMS, ITP dsb, di SMP Negeri AKPD, AUM, DCM, ITP, IKMS, MBTI.

Hasil penelitian Putranti (Putranti, 2015), menunjukkan ada dua alasan yang cukup kuat yang menghambat ketersediaan sarana dan prasarana bimbingan dan konseling yaitu faktor biaya dan keterbatasan lahan. Hasil kajian ini menggambarkan bahwa keadaan sarana dan prasarana BK di SMP dan SMA Negeri di Indonesia masih belum memadai terutama ketersediaan rungan khusus konseling individual yang mayoritas $80 \%$ sekolah belum memilikinya, hal ini perlu menjadi perhatian berbagai pihak terutama pemerintah yang sudah tujuh tahun dikeluarkannya Permendikbud No 111 Tahun 2014 sebagai standar pelayanan minimal BK di satuan pendidikan dasar dan menengah. Dengan terpenuhinya sarana dan prasarana sesuai standar diharapkan pelayanan BK akan mampu memberikan pelayanan yang profesional dan bermartabat dan terhindar dari miskonsepsi dan malpraktik pelayanan (Pohan \& Ramadhani, 2018).

Kajian ini telah memberikan gambaran keadaan sarana dan prasarana BK di SMP dan SMA Negeri di Indonesia, meskipun demikian kajian ini masih memiliki keterbatasan terutama dalam pengambilan sampel yang belum bias secara stratified dikarenakan begitu luasnya wilayah Indonesia, meskipun demikian secara sampel sudah dapat mewakili, kemudian kajian ini hanya melihat pada sekolah negeri, kajian berikutnya dapat melihat keadaan sekolah swasta untuk dapat mengkur secara keseluruhan standar sarana dan prasarana BK pada satuan pendidikan di Indonesia. Rekomendasi untuk kajian dan penelitian berikutnya juga dapat melakukan analisis kebijakan mengenai aspek dan regulasi serta implementasi BK di Indonesia, sehingga dapat menyentuh akar masalah yang dapat diselesaikan terlebih dahulu baik secara kualitatif maupun kuantitatif.

\section{SIMPULAN}

Kajian ini menyimpulkan bahwa secara keseluruhan standar minimal sarana dan prasarana BK pada SMP, SMA dan SMK Negeri di Indonesia belum terpenuhi dan tergolong rendah. Hal yang paling 
memperihatinkan adalah ketersediaan ruangan konseling individu yang hanya dimiliki oleh $20 \%$ sekolah dari keseluruhan sekolah yang menjadi sampel penelitian, hal inilah yang paling menganggangu kenyamanan Guru BK dan Siswa padahal konseling individu merupakan jantung hatinya pelayanan konseling.

\section{DAFTAR PUSTAKA}

Bhakti, C. P. (2018). Ketersediaan sarana dan prasarana bimbingan dan konseling di sekolah menengah di Kabupaten Gunungkidul. Jurnal Pendidikan (Teori Dan Praktik), 2(2), 100.

https://doi.org/10.26740/jp.v2n2.p100 $-104$

BSNP. (2006). Permendiknas RI No. 22 Tahun 2006 tentang standar isi untuk satuan pendidikan dasar dan menengah. Permendiknas RI.

Farozin, M., Suwarjo, S., \& Astuti, B. (2017). Identifikasi permasalahan perancangan program bimbingan dan konseling pada guru SMK di Kota Yogyakarta. Jurnal Penelitian Ilmu Pendidikan, 10(1), 40-52. https://doi.org/https://doi.org/10.218 31/jpipfip.v10i1.16795

Fatchurahman, M. (2018). Problematik pelaksanaan konseling individual. Jurnal Bimbingan Dan Konseling ArRahman, 3(2), 25-30.

Fitria, L., Neviyarni, S., Syukur, Y., \& Ahmad, R. (2021). Sarana dan prasarana sebagai penunjang kegiatan bimbingan dan konseling di sekolah menengah kejuruan. $A L^{-}$
IRSYAD, 11(1), 15-21.

Haolah, S., Atus, A., \& Irmayanti, R. (2018). Pentingnya kualitas pribadi konselor dalam pelaksanaan konseling individual. FOKUS (Kajian Bimbingan $\mathcal{E}$ Konseling Dalam Pendidikan), 1(6), 215-226.

Hikmawati, F. (2016). Bimbingan dan konseling. Rajawali Press.

Indrawan, I. (2015). Pengantar manajemen sarana dan prasarana sekolah. Deepublish.

Intishar, F., Chanum, I., \& Badrujaman, A. (2015). Pemenuhan standar sarana dan prasarana bimbingan dan konseling (Survei terhadap sekolah menengah atas negeri di Jakarta Barat). INSIGHT: Jurnal Bimbingan Konseling, 4(1), 25-31. https://doi.org/https://doi.org/10.210 09/INSIGHT.041.05

Kemendikbud. (2014). Peraturan menteri pendidikan dan kebudayaan Republik Indonesia Nomor 111 Tahun 2014 tentang bimbingan dan konseling pada pendidikan dasar dan pendidikan menengah. In Kemendikbud RI.

Kemendiknas. (2007). Peraturan Menteri Pendidikan Nasional Republik Indonesia Nomor 24 Tahun 2007 tentang standar sarana dan prasarana untuk sekolah Dasar/Madrasah Ibtidaiyah (SD/MI), Sekolah Menengah Pertama/Madrasah Tsanawiyah (SMP/Mts), dan Sekolah Menengah Atas/Madrasah A. Kemendikbud.

Marimbun. (2021). Meningkatkan minat membaca mahasiswa melalui 
bimbingan kelompok topik tugas. Jurnal KOPASTA, 8(1), 54-65.

Marimbun, M. (2019). Minat membaca dan implementasinya dalam bimbingan dan konseling. ENLIGHTEN: Jurnal Bimbingan Konseling Islam, 2(2), 7484.

https://doi.org/10.32505/ENLIGHTE N.V2I2.1361

Novita, M. (2017). Sarana dan prasarana yang baik menjadi bagian ujung tombak keberhasilan lembaga pendidikan islam. Nur El-Islam, 4(2), 97-129.

Pohan, R. A., \& Indra, S. (2020). Efektivitas layanan bimbingan kelompok dalam meningkatkan kegiatan merespon pembelajaran. Islamic Counseling : Jurnal Bimbingan Dan Konseling Islam, $4(1)$, $17-30$ https://doi.org/10.29240/JBK.V4I1.12 80

Pohan, R. A., \& Ramadhani, E. (2018). Miskonsepsi prodi BPI/BKI fakultas Dakwah di PTKIN. Biblio Couns, 1(2), 54-58.

https://doi.org/https://doi.org/10.305 96/bibliocouns.v1i2.2079

Prayitno. (2004). Seri layanan konseling. FIP UNP.

Prayitno. (2012). Jenis layanan dan kegiatan pendukung konseling. Padang: Program PPK FIP UNP.

Putranti, D. (2015). Studi deskriptif tentang sarana dan prasarana bimbingan dan konseling di sekolah menengah pertama. PSIKOPEDAGOGIA Jurnal Bimbingan Dan Konseling, 4(1), 45-50.

Romlah, T. (2001). Teori dan praktek bimbingan dan konseling kelompok. Universitas Negeri Malam Press.

Setyaningrum, D. (2013). Pengaruh persepsi siswa tentang layanan konseling individu dan persepsi siswa tentang kompetensi kepribadian konselor terhadap minat memanfaatkan layanan bimbingan dan konseling. Jurnal $B K$ UNESA, 3(1).

Sugiarto, S., Neviyarni, S., \& Firman, F. (2021). Peran penting sarana dan prasarana dalam pembelajaran bimbingan konseling di sekolah. JPT: Jurnal Pendidikan Tematik, 2(1), 60-66.

Tim Penyusun Panduan Bimbingan Dan Konseling Sekolah Dasar, Sekolah Menengah Pertama, Sekolah Menengah Atas, D. S. M. K. (2016). Panduan operasional penyelenggaraan bimbingan dan konseling Sekolah Menengah Atas (SMA).

Widodo, B. (2019). Manajemen konseling individual (studi kasus: pelaksanaan konseling individual di SMP N 7 Madiun). In. Prosiding SNBK (Seminar Nasional Bimbingan Dan Konseling), 3(1), 24-30.

Zahara, C. I. (2017). Hubungan persepsi siswa terhadap konselor dan sarana prasarana bimbingan konseling dengan minat layanan konseling di SMP Negeri 2 Dewantara Kabupaten Aceh Utara. Analitika: Jurnal Magister Psikologi UMA, 9(1), 10-20. 
Gambaran Sarana dan Prasarana... - Marimbun \& Rizky Andana Pohan 